
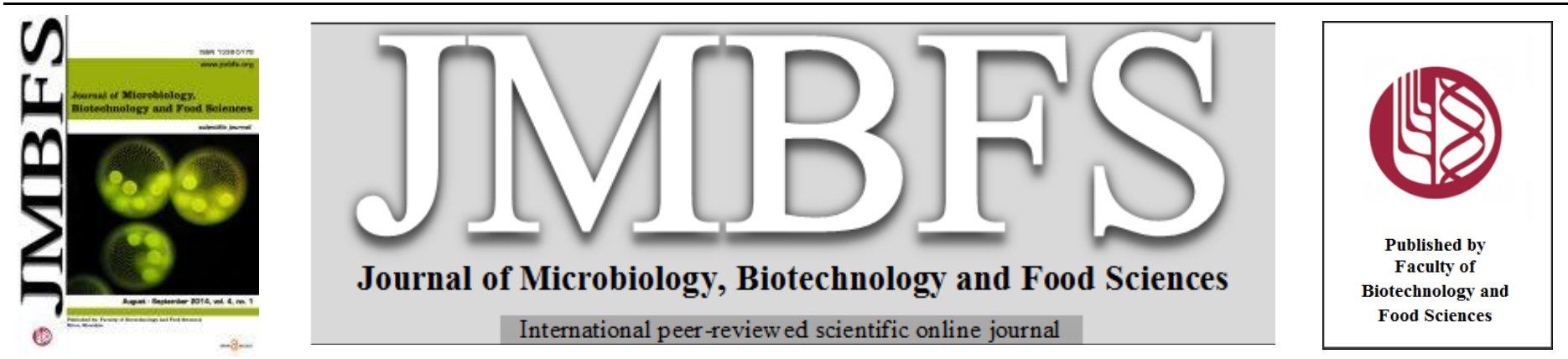

\title{
EXPRESSION OF BACTERIAL PROTEIN-A IN TOBACCO LEADS TO ENHANCED RESISTANCE TO STRESS CONDITIONS
}

\author{
Chaitali Roy*', Anamika Ray ${ }^{2}$, Yasmin Begum ${ }^{1}$ and Priyanka Paul ${ }^{1}$ \\ Address(es): Chaitali Roy, \\ ${ }^{1}$ Bose Institute, Division of Plant Biology, 93/1 Acharya Prafulla Chandra Road, Kolkata-700009, West Bengal, India. \\ ${ }^{2}$ Indian Association for the cultivation of Science, Jadavpur, Kolkata-700032, West Bengal, India.
}

*Corresponding author: croy.bi@gmail.com

doi: 10.15414/jmbfs.2014.4.1.75-79

\section{ARTICLE INFO}

Received 16. 1. 2014

Revised 9. 7. 2014

Accepted 11. 7. 2014

Published 1. 8. 2014

Regular article

OPEN $\partial_{\text {ACCESS }}$

\begin{abstract}
Tobacco is the most commonly used plant for expression of transgenes from a variety of organisms because it can be easily grown and transformed, it provides abundant amounts of fresh tissue and has a well-established cell culture system. As bacterial enzymes can be synthesized in tobacco, here we explore the possibility of in planta expression of staphylococcal protein-A(PA) which is an antibody, an important group among biopharmaceuticals. In our study we have shown that the tobacco plants harboring PA gene could combat the crown gall infection and also effective in resisting abiotic stress conditions. Transgenic plants when subjected to interact with wild variety of Agrobacterium shows its enhanced capability to resist the gall formation. And when transgenic tobacco plants were grown in presence of $200 \mathrm{mM} \mathrm{NaCl}$ and/or MG(Methylglyoxal) solution, shows their increased tolerance towards salinity stress and high MG stress. So far transgenic tobacco plants are concerned, improvements in the expression of recombinant proteins and their recovery from
\end{abstract} tobacco may also enhance production and commercial use of this protein.

Keywords: Staphylococcal-proteinA, IgG, Agrobacterium, transformation, methylglyoxal, crown gall, salt stress

\section{INTRODUCTION}

Tobacco plants are extremely versatile vehicle for all cell and tissue culture research. The majority of discoveries in the field of plant cell/tissue culture and molecular biology have originated from experiments with tobacco plants. Tobacco is used for expression of transgenes from a variety of organisms. Among the many genes from different organisms expressed in tobacco plants, genes of bacterial origin are most common and also human protein (Jeffrey $\boldsymbol{e}$ al., 2000). In this study bacterial gene (proteinA) has been used to genetically engineer tobacco for a variety of purposes, including studies on resistance to pathogens, tolerance to abiotic stresses.

Plants are sessile and sensitive organisms that inevitably encounter a variety of biotic and abiotic stresses in nature. One of the most serious problems in agriculture is the loss of productivity caused by plant pathogens. Salinity stress is another environmental threat. Vegetable production is highly threatened by increasing soil salinity reducing productivity. Physiological salinity imposes an initial water deficit that results from the high solute concentration causing altered $\mathrm{K}^{+} / \mathrm{Na}^{+}$ratios and leads to a buildup in $\mathrm{Na}^{+}$and $\mathrm{Cl}^{-}$concentrations that are detrimental for plants (Yamaguchi and Blumwald, 2005). To cope with the constant threat of invasion by pathogens and other environmental stress, plants evolved over time different mechanisms to protect themselves. For a plant to establish a successful self-defence response against different stresses, many genes known to be involved in such defence mechanism have been identified and expressed in transgenic tobacco plants. The genetically transformed plants carrying these genes showed spontaneous activation of different defence mechanisms, leaving the plant in a heightened state of defence. Tobacco plants have been in dynamic use and widely assayed as a production platform for recombinant proteins and including subunit vaccines (Warzecha and Mason, 2003; Streatfield, 2007) also. In the last twenty years, many recombinant therapeutic proteins have been expressed in plant production platforms (Giddings, 2000; Ko, 2009) and the potential of large-scale production of pharmaceutical proteins using plant bioreactors as efficient and economical systems has been demonstrated (Lau, 2009). However, there are only a few reports on the expression of Staphylococcal Protein-A in plants. Protein A is a bacterial protein from Staphylococcus aureus. Recombinant Staphylococcal Protein A is often produced in E. coli for use in immunology and other biological research. It has found use in biochemical research because of its ability to bind immunoglobulins. It is composed of five homologous Ig-binding domains that fold into a three-helix bundle. Each domain is able to bind proteins from many of mammalian species, most notably Immunoglobulin $\mathrm{G}(\mathrm{IgG})$ (Almerigogna et al., 1982).

Plants cannot survive unless they are able to cope with environmental changes and pathogen attacks- In order to combat such adverse conditions, plants have its own defence mechanism where the glyoxalase system and reactive oxygen species (ROS) detoxification systems play regulatory roles in plant stress tolerance and have increasingly attracted much interest because excessive production of ROS and methylglyoxal (MG) is a common consequence of both abiotic and biotic stresses in plants (Veena et al., 1999; Chen et al., 2004; Yadav et al., 2005a, 2005b; Singla-Pareek et al., 2006; Hossain and Fujita, 2009, 2010, 2011; Banu et al., 2010; El-Shabrawi et al., 2010). ROS and MG are highly toxic to plant cells, and in the absence of adequate protective mechanisms, they can react with proteins, lipids and nucleic acids and inactivate the vital defence system leading to irreparable metabolic dysfunction and death. Plants have a complex network of enzymatic and non-enzymatic scavenging pathways or detoxification systems which function as an extremely efficient cooperative system to counter the deleterious effects of ROS and MG as well as to perform their signalling function. In plants, MG is detoxified mainly via the glyoxalase system. Besides detoxification of MG, the glyoxalase system could also play a role in oxidative stress tolerance by recycling reduced glutathione (GSH) that would be trapped nonenzymatically by MG to form hemithioacetal, thereby maintaining glutathione homeostasis (Hossain, 2010). In addition, ROS levels are controlled via a versatile antioxidant network in plants. The specific interplay between ROS and components of the antioxidant and glyoxalase pathways could generate compartment-specific changes in both the absolute concentrations of ROS, MG and antioxidant compounds as well as in the ascorbate and glutathione redox ratios (Hossain, 2011). Under stress conditions, these redox signals could interfere with the signalling networks complementary to the antioxidant system and regulate defence gene expression, thus coordinating the necessary readjustments in the redox-regulated plant defence to overcome oxidative stress (Foyer and Noctor, 2005a,2005b, 2011; Kuźniak, 2010; Mhamdi et al., 2010).

Here in our work we mainly focussed on the change in the plant behaviour against the stresses like crown gall infection, salinity and high concentration of methylglyoxal. To achieve this, tobacco plants were transformed with PA gene by Agrobacterium mediated transformation, 
few transformants were selected for different experiments. Further infection of selected transgenic and WT(wild type) plants with an another wild variety of Agrobacterium (ATCC15955) for crowngall formation, was carried out to see whether there is any effect on crown gall formation. To some extent it was found that growth of crowngall formation was checked. As galls can grow independently and can proliferate without any exogenous application of phytohormones, surprisingly it was observed that crown gall detached from PAtobacco plants failed to proliferate on MSO(Murashige-Skoog) media whereas crown gall from WT plants could grow in MSO media. The cellular mass of the crown gall developed in the tobacco plants harboring PA gene, first became brown and subsequently failed to grow/survive further.

\section{MATERIAL AND METHODS}

\section{Cloning of Protein-A(derived from plasmid pRIT2T) in pBI121}

Plasmid DNA was isolated from the Escherichia coli N4830-1 harboring pRIT2T(Amersham Pharmacia Biotech, Uppsala, Sweden) using alkaline lysis method. Protein-A amplified from the plasmid DNA, using PA3 forward and PA5 reverse primers, was subcloned in the plant expression vector pBI121 (Clonetech, Washington, DC, USA) after the removal of the $\beta$-Glucuronidase (GUS) reporter gene to yield the recombinant pBI121: PA (-GUS) with nptII as the selectable marker. The sequences of all the primers are shown in Table 1. DNA manipulations and cloning were carried out following standard procedures (Sambrook and Russel, 2001). The pBI:PA construct was transferred into the competent cells of Agrobacterium tumefaciens LBA4404 strain by liquid nitrogen freeze thaw method (An, 1987).

Table 1 List of different oligonucleotide primers used

\begin{tabular}{ll}
\hline Primer & Nucleotide sequences \\
\hline PA- & 5'GGTAGAGCTCTGCAGGTCGACGGATCCCCGGGAAT \\
3(Forward) & TCCCCGCATC3' \\
\hline PA- & 5'GATCTCTAGAACAATGGAACAACGCATAACCCTGA \\
5(Reverse) & A3' \\
\hline
\end{tabular}

\section{Plant transformation procedure}

Well grown leafy tobacco plants in bottles were taken for Agrobacterium mediated transformation. Tobacco leaf discs (1-2 inch in length) were infected with Agrobacterium tumefaciens LBA4404 strain containing pBI: PA (Horsch, 1988; Roychowdhury, 2007). After 2 days of co-cultivation in the dark at $26^{\circ} \mathrm{C}$ the leaf discs were transferred to the regeneration medium supplemented with cefotaxim $\left(250 \quad \mathrm{mg} \mathrm{l}^{-1}\right)$ and kanamycin $\left(100 \mathrm{mg} \mathrm{l}^{-1}\right)$ and BAP (Benzylaminopurine, $0.5 \mathrm{mg} \mathrm{l}^{-1}$ ). The cultures were maintained at $26^{\circ} \mathrm{C}$ under continuous illumination. Shoot bud differentiation started after 14-16 days of culture, which elongated into shoots within 30-35 days. After profuse rooting in the rooting medium containing NAA(Naphthalene acetic acid, $0.1 \mathrm{mg} \mathrm{l}^{-1}$ ), the T0 plants were allowed to flower and set seeds under normal environmental conditions by preventing cross-pollination. Seeds collected were germinated on medium containing kanamycin $\left(100 \mathrm{mg} \mathrm{l}^{-1}\right)$ to raise $\mathrm{T} 1$ seedlings, which were maintained to full growth at $25 \pm 2{ }^{\circ} \mathrm{C}$ and $16 \mathrm{~h} \mathrm{light} / 8 \mathrm{~h}$ dark cycle in the culture room and used for next experiments.

\section{Polymerase chain reaction $(\mathbf{P C R})$}

Genomic DNA was isolated from the young leaf tissues of WT and transge tobacco plants according to the modified CTAB method Murray et al.(198 PCR amplification of the transgene was done using PA-5 and PA-3 prim (Table 1).

Total RNA was extracted from control tobacco leaf and leaves from 6 putati $\mathrm{T} 1$ transgenic tobacco plants $(6 \mathrm{hrs}$ of $200 \mathrm{Mm} \mathrm{NaCl}$ induction) following 1 method of Longhurst (1994). RNA samples were treated with RNasefree DN: I (Fermentus). RT reactions were carried out with $50 \mathrm{ng}$ of total RNA usi Sensiscript RT-PCR system kit (Qiagen). The primer pairs used for RT-P( were PA-5 and PA-3, whose sequences are given in Table 1.

\section{Inheritance analysis}

Seeds collected from five transformed plants (T0) were sterilized and germina1 on MS basal medium supplemented with $100 \mathrm{mg} \mathrm{L}^{-1}$ kanamycin. The plates w incubated under the conditions as described for in vitro culture. After 3-4 wee kanamycin sensitive seedlings germinated but bleached quickly, wher resistant seedlings were green and formed true leaves and roots. The plants (T were analyzed for the presence of the PAgene by genomic PCR and RT-P( respectively.

\section{$\mathrm{NaCl}$ and MG tolerance assay and growth performance analysis}

T0 seeds from four transgenic lines(L/1, L/3, L/13 and L/14) were germinated in the dark at $25^{\circ} \mathrm{C}$ on kanamycin-containing $\left(100 \mathrm{mg} \mathrm{l}^{-1}\right) \mathrm{MS}$ medium. The 10 -day- old surviving seedlings were then transferred to kanamycin-containing plain $1 / 4^{\text {th }}$ MS liquid medium and kept for a month. Now these plantlets from each of those 4 lines were transferred in $1 / 4^{\text {th }}$ MS supplemented with $100 \mathrm{mM} / 200 \mathrm{mM} / 400$ $\mathrm{mM} / 800 \mathrm{mM} \mathrm{NaCl}$ for imposing salinity stress to see the effect of $\mathrm{NaCl}$ stress on different transgenic lines. The seedlings were maintained under culture room conditions at $25^{\circ} \mathrm{C}$ and the plant responses to salt stress was monitored for another 7 days against WT.

Similarly, in another set, T0 seeds from those four transgenic lines were germinated in the dark at $25^{\circ} \mathrm{C}$ on kanamycin-containing $\left(100 \mathrm{mg} \mathrm{l}^{-1}\right) \mathrm{MS}$ medium. The 10-day-old surviving seedlings were then transferred to kanamycincontaining either plain 1/4th MS liquid medium and kept for a month. After that the plantlets from each of those four lines were transferred to $1 / 4^{\text {th }} \mathrm{MS}$ supplemented with $2.5 \mathrm{mM} / 5.0 \mathrm{mM} / 10 \mathrm{mM}$ MG for imposing stress (before considering the concentration of MG, we tested the tolerance level of 10day old tobacco seedlings). The plantlets were maintained under culture room conditions at $25^{\circ} \mathrm{C}$ and the plant responses to MG-stress was monitored for another 7 days against WT.

\section{Formation of crowngall in tobacco}

Wild Agrobacterium strain (ATCC 15955) were cultured on solid YEP (Bacto peptone $1 \% \mathrm{w} / \mathrm{v}, \mathrm{NaCl} 0.5 \% \mathrm{w} / \mathrm{v}$, Yeast extract $1 \% \mathrm{w} / \mathrm{v}$ and Agar $1.5 \%$ ) medium. 2day old Agrobacterium cells were taken and diluted with $1 / 2$ MS liquid medium. Then the cell suspension was applied on the shoots of tobacco( 2 month old) grown in vitro in solid MS media. Before infecting the shoot, the site was pinched with sterile needle. After 15 days the gall started forming (Ray, 2011).

\section{RESULTS}

Production and molecular characterization of transgenic tobacco plants overexpressing the full length PA gene from pRIT2T (a staphylococcal protein)

The structure of the plasmid pBI121, with inserted PA gene at XbaI and SacI site (after the removal of the $\beta$-Glucuronidase- 'GUS') has been shown in Fig.1. Tobacco leaf discs were transformed with the recombinant plasmid pBI121:PA(GUS) via Agrobacterium-mediated transformation. 10 regenerated putative transgenic T0 plants, resistant to kanamycin, were selected and advanced to T1 generation. The transgenic plants showed normal phenotype with similar morphology, vegetative growth or development and flowering periods. They were completely fertile, producing huge amounts of seeds. The T0 plants were self-pollinated to obtain segregating T1 progeny. Few selected lines(pre-selected by growing the seeds aseptically in solid MSO media containing $100 \mathrm{mg} \mathrm{l}^{-1}$ Kanamycin) were analyzed by genomic DNA PCR (Fig. 2A) which confirmed the introgression of the gene into tobacco genome. The PA transcript of approximately $0.8 \mathrm{Kbp}$ was detected by RT-PCR analysis from transgenic plants $\mathrm{T} 1 / 1, \mathrm{~T} 1 / 3, \mathrm{~T} 1 / 13$ and $\mathrm{T} 1 / 14$, but no product was visible from WT plants (Fig. 2B). PCR with no-RT reaction using each RNA sample did not show any product (data not shown). Digestion of genomic DNA from T1 transgenic plants T1/1, T1/3, T1/13 and T1/14 with XbaI and SacI released the $0.8 \mathrm{Kbp}$ fragment of PA full-length gene as evidenced.

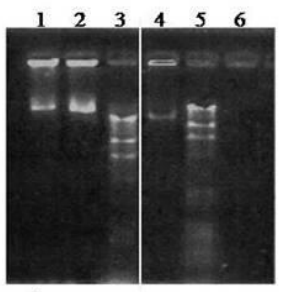

A

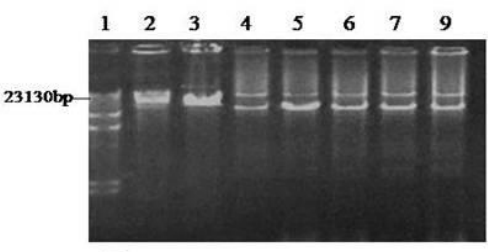

B

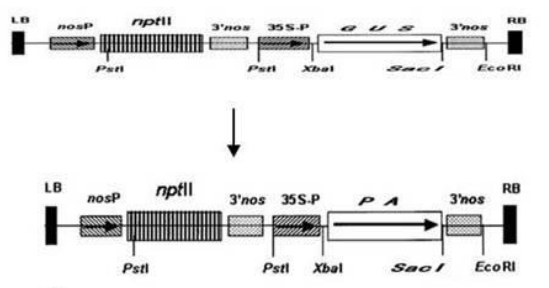

C

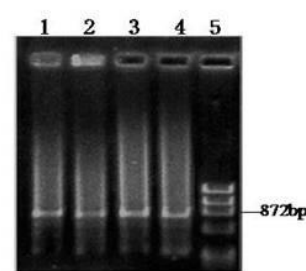

D
Figure 1 Cloning of PA-gene in pBI121 binary expression vector for Agrobacterium (LBA4404)-mediated tobacco transformation. (A).pRIT2T plasmid in Lane number 1, 2 and 4. Lane 3 and 5 are $\lambda$ HindIII marker. (B).Lane1 is $\lambda$ HindIII Marker. Lane 2 and 3 are untransformed pBI121 Plasmid. Lane 4-9 are recombinant pBI121-PA from different colonies. (C).Physical map of the Ti-based binary expression vector pBI121 
showing the introgression of the $0.8 \mathrm{Kbp}$ full-length Protein-A gene amplified from pRIT2T expression vector(Pharmacia), at XbaI and SacI site, after the removal of the $1.2 \mathrm{Kbp}$ GUS gene. (D). Colony PCR from transformed Agrobacterium LBA4404 with PA gene.

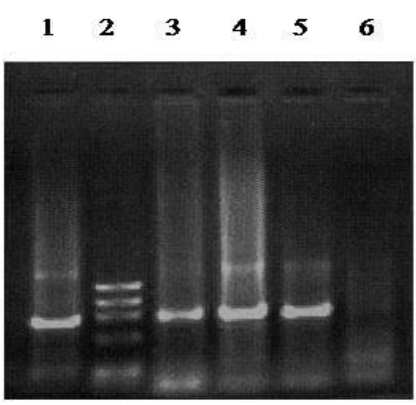

A

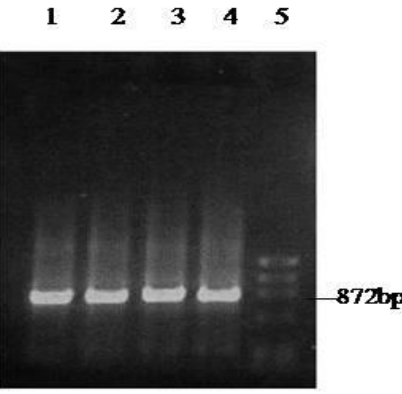

B
Figure 2 Analysis of the putative transgenic plants by polymerase chain reaction. (A). Lane 1,3,4,5 shows the PCR amplified product from putative T1 transgenic plants for the presence and integration of $0.8 \mathrm{Kbp} \mathrm{PA}$ full-length gene within their genome by genomic DNA PCR transgenic tobacco plant(T1).Lane 6 shows no product from control tobacco plant. Lane 2 shows the $\varphi$ x DNA Molecular Marker. (B). Detection of the transcript for PA transgene in the T1 transgenic plants by RT-PCR. RT-PCR done with exracted RNA fromT1/1(Lane1), T1/3(Lane2), T1/13(Lane3), T1/14(Lane14) transgenic leaves. Lane 5 shows the $\varphi$ x DNA Molecular Marker. (The control WT plants gave no RT-PCR product).

Analysis of T1 transgenic tobacco plants in response to several exogenous stress treatments

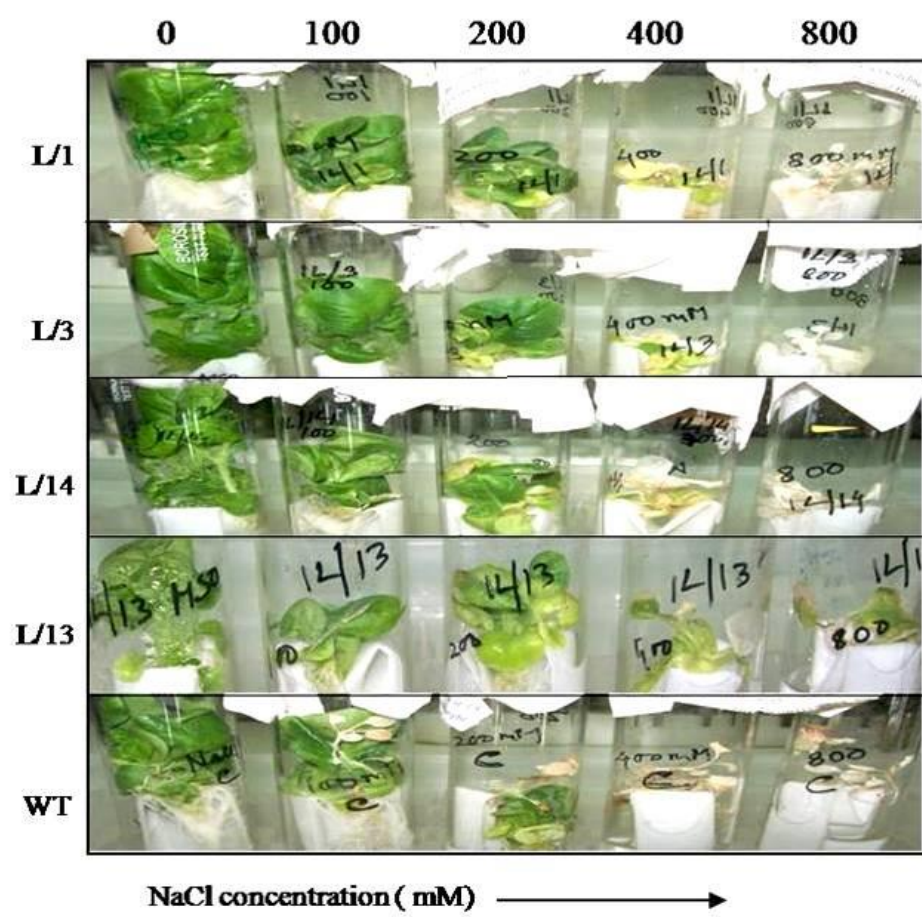

Figure 3 Increased tolerance of the T1 transgenic tobacco plants to high levels of salinity. The growth of 1 month-old transgenic plants (linesT1/1, T1/3, T1/13 and T1/14) was compared with the WT (untransformed) plants by transferring them to various concentrations $(0,100,200,400$ and $800 \mathrm{mM})$ of $\mathrm{NaCl}$ and monitoring their growth for 7 days. A noteworthy observation was the better growth performance of transgenic plants that showed near-normal phenotype with marginal growth reduction even at $200 \mathrm{mM} \mathrm{NaCl}$ providing evidence for functional expression in planta of the transgene following introgression. In case of WT plants, the effect was severe even from $200 \mathrm{mM} \mathrm{NaCl}$ showing prominent growth inhibition. At 400 or $800 \mathrm{mM} \mathrm{NaCl}$, practically all the WT seedlings became totally bleached out or drastically wilted within $10-15$ days and could not survive beyond that level.
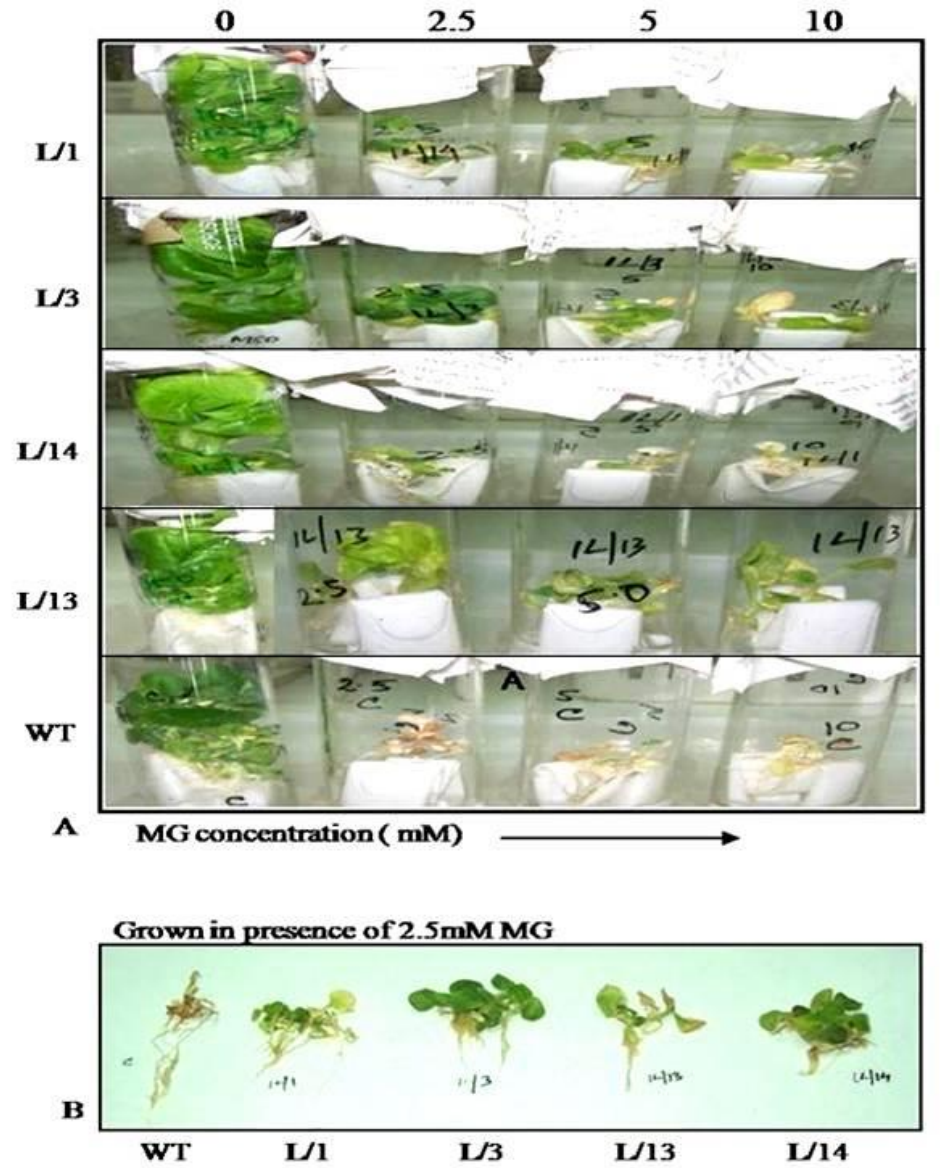

Figure 4 Increased tolerance of the T1 transgenic tobacco plants to increasing concentration of exogenous MG. (A).The growth of 1 month-old transgenic plants T1/1, $\mathrm{T} 1 / 3, \mathrm{~T} 1 / 13$ and T1/14 was compared with the WT (untransformed) plants by transferring them to various concentrations $(0,2.5,5.0$ and $10 \mathrm{mM})$ of $\mathrm{MG}$ and monitoring their growth for 7 days. A noteworthy observation was that, the effect of MG stress on overall growth was much less in transgenic plants than in WT plants, providing evidence for functional expression in planta of the transgene following introgression. In case of WT plants, the effect was severe even in $2.5 \mathrm{mM} \mathrm{MG}$ showing prominent growth inhibition. At higher dose than that found fatal for WT plants, became totally bleached out, could not survive beyond that level. (B).Effect of 2.5mM MG on growth of T1 transgenic and WT plants.

Increased resistance of the $\mathrm{T} 1$ transgenic plants to crown gall formation when infected with wild Agrobacterium (ATCC 15955)

The 2 month old transgenic plants from four different lines (T1/1, T1/3, T1/13 and T1/14) grown in solid MSO media along with the WT (untransformed) plants were infected with wild crown gall forming Agrobacterium (ATCC 15955). It was noted that crown galls formed in transgenic plants were smaller in sizes than that of the WT plants (Fig. 5). Crown galls detached from the stems were further cultured in hormone free solid MS for monitoring their capability to proliferate independently. As in Fig. 6, it could be easily seen the difference in the growth of galls. Crown galls formed on transgenic plants could not survive when subcultured in solid MS media whereas crown galls formed on WT plants(C) could grow when subcultured.

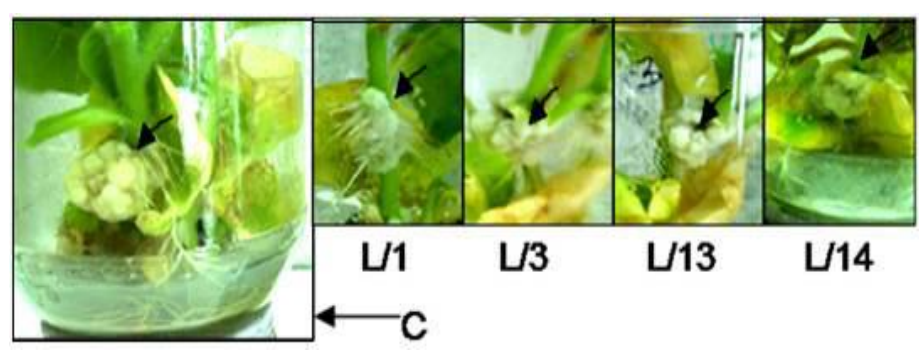

Figure 5 Crown gall formation in WT and differentt lines of transgenic (transformed with PA gene) tobacco plants. Two month old transgenic and contro tobacco plants which were grown in solid MSO medium (WT and T1 transgenic plants $\mathrm{T} 1 / 1, \mathrm{~T} 1 / 3, \mathrm{~T} 1 / 13$ and $\mathrm{T} 1 / 14$ were infected with wild Agrobacterium(ATCC 15955). Gal formation in the transgenic plants were found restricted so far size is concerned. 


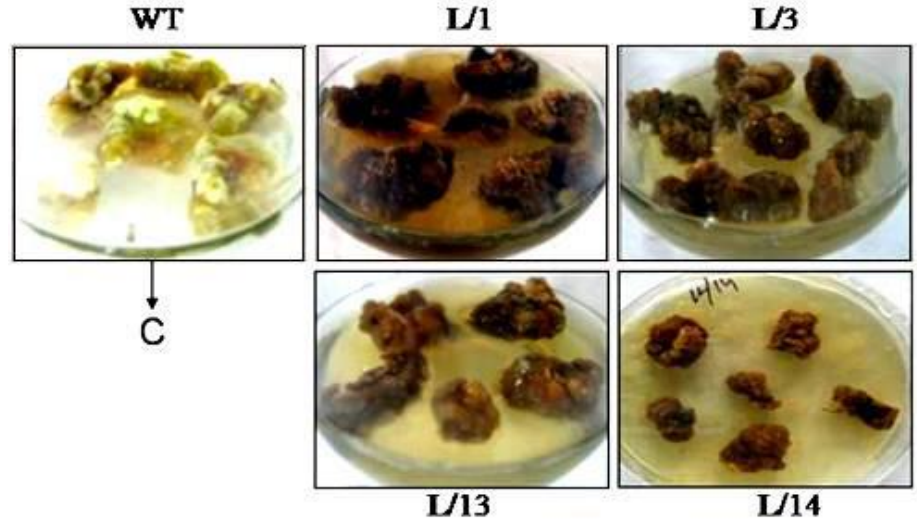

Figure 6 Independent growth pattern of detached galls of WT and different lines of transgenic(transformed with PA gene) tobacco plants. Crown gall can grow independently without any growth regulators. The picture shows, crown gall when subcultured in solid MSO medium, WT plants were found growing normally and are green whereas galls of transgenic plants when cultured could not survive further.

\section{DISCUSSION}

Plants are an extremely versatile expression platform for recombinant therapeutic proteins. In our results it has been shown that a bacterial sequence can function in plant cells. Transgenic tobacco expressing bacterial PA showing decreased susceptibility to crown gall infection caused by wild Agrobacterium and at the same time it also conferred enhanced resistance to high concentration of $\mathrm{NaCl}$ or high concentration of MG (methylglyoxal). Such responses varied among the transformed plants. It is not clear what causes the differences, especially between the lines.

MG is both a mutagen and a genotoxic agent. At high cellular concentration, it inhibits cell proliferation (Ray et al., 1994) and results in a number of adverse effects such as increasing the degradation of proteins through the formation of advanced glycation end products (AGEs) and inactivating the antioxidant defence system (Wu and Juurlink, 2002; Hoque et al., 2010). Additionally, MG causes increased sister chromatic exchange and endoreduplication and also induces DNA strand breaks and increases point mutations (Chaplen, 1998). Therefore, efficient detoxification of MG overproduced during various abiotic or biotic stresses is one of the most important adaptive strategies of plant stress tolerance. Genes expressed during $\mathrm{NaCl}$ and high $\mathrm{MG}$ stress are anticipated to promote cellular tolerance through protective functions in the cytoplasm, alteration of cellular water potential to promote water uptake, control of ion accumulation and further regulation of gene expression. Although these studies are promising, it continues to be difficult to ascertain the actual functions of salinity induced gene products (Bray, 1993). In our study, an RT-PCR amplicon of 800bp was observed in transgenics and no band was noticed in control tobacco, which implies the expression of the transgene at the transcription level. Prior to RNA extraction from leaves, the transgenics and control plants were given induction of $200 \mathrm{mM} \mathrm{NaCl}$ for 6 hours in order to ensure /intensify the transcript. The transgenic plants conferred enhanced resistance to high concentration of $\mathrm{NaCl}$ and MG stress. The results show that a bacterial protein can function in plant cells. Since plants are sessile, they have developed mechanisms that enable them to sense stresses and to elicit complex interactions between signalling molecules and pathways to adapt to various stresses. In response to abiotic stress, small molecules such as abscisic acid (ABA) and calcium are utilized by the plant to induce various signaling cascades. These pathways use various proteins such as phospholipases, kinases, calmodulin, calcium-binding proteins and transcription factors to activate genes necessary for waterrelated stress tolerance (Xiong $\boldsymbol{e t}$ al., 2002; Chinnusamy et al., 2003; Munns, 2005; Yamaguchi-Shinozaki and Shinozaki, 2006). Another family of signaling proteins involved in many aspects of cellular maintenance and plant development are the GTPases which are grouped into two major classes, the small GTPases and the heterotrimeric G proteins (Assmann, 2002; Yang, 2002). The results described herein provide a valuable first step towards elucidating the role of this gene and its signaling cascade in stress responses. More in depth studies have to be done in order to explore by which pathway probably the this bacterial protein operates in plant system.

To further verify the significance of this observation the transformed plants were again subjected to Agrobacterium infection for crown gall formation. Though crowngall generation was noticed but it was certainly lesser and degree of infection varied among the lines. When crown galls developed in the $\mathrm{T} 1$ tobacco-PA plants were separated and allowed to grow independently aseptically in nutrient media, it was found that except the control (crown gall formed in the WT plant) one none of them could multiply or survive. So this finding is consistent with the previous findings in this study. The usefulness of the cloned PA construct can be checked and deployed in other crops plants also.
Antibodies represent the largest group of biopharmaceuticals. Due to the nature of their clinical applications, they often need to be produced in large quantities. Plants have distinct advantages of producing large quantities of recombinan proteins, and tobacco is arguably the most promising plant for plant-madepharmaceuticals (PMP) due to its high biomass yields and robust transformation technology. However, to produce proteins using transgenic tobacco for human applications, purification of the proteins is challenging.

\section{CONCLUSION}

In conclusion, our findings related to the ability of transgenic tobacco to produce recombinant protein PA which is not only capable of resisting crowngall infection but also could combat $\mathrm{NaCl}$ and high $\mathrm{MG}$ stress. This provides support for a novel defence function for biotic and abiotic stress. Plants are an extremely versatile expression platform for recombinant therapeutic proteins. In recent years, transgenic plants have become one of the most promising substrates to produce pharmaceutical recombinant proteins at a reasonable cost and with high biological security standards, especially in vaccine production. So far versatility of such bacterial potein in plant defense mechanism is concerned, more studies are needed and the key question will need to be resolved before we can claim full understanding of the mode of the signalling cascade leading to the induction of the PA and reduced susceptibility to stresses including plant diseases.

Competing interests: The authors declare that they have no competing interests.

Authors' contributions: CROY conceived the study, participated in its design, carried out construct preparation, Agro-mediated tobacco transformation, molecular analysis and drafted the manuscript. AR,YB and PP grew and maintained the plants in containment and participated in collection of plant material.

Acknowledgments: Authors thank Division of Plant Biology and the Director Prof Sibaji Raha of Bose Institute for financial help. Thanks to Prof. DN Sengupta of DPB for giving the pRIT2T vector and special thanks to Dr Anamika Ray of IACS for providing the wild strain of Agrobacterium (ATCC 15955).

\section{REFERENCES}

AN, G. 1987. Binary Ti vectors for plant transformation and promoter analysis Method. Enzymol., 153, 292-293. http://dx.doi.org/10.1016/00766879(87)53060-9

ASSMANN, S. 2002. Heterotrimeric and unconventional GTP binding proteins in plant signaling. Plant Cell,14,355-73.

BANU, M.N.A., HOQUE M.A., WATAMABLE-SUGIMOTO, M., ISLAM, M.A., URAJI, M., MATSUOKA, M., NAKAMURA, Y., MURATA, Y. 2010 Proline and glycinebetaine ameliorated $\mathrm{NaCl}$ stress via scavenging of hydrogen peroxide and methylglyoxal but not superoxide or nitric oxide in tobacco cultured cells. Bioscience Biotechnology and Biochemistry, 74(10), 2043-2049. http://dx.doi.org/10.1271/bbb.100334

CHAPLEN, F.W.R. 1998. Incidence and potential implications of the toxic metabolite methylglyoxal in cell culture: A review. Cytotechnology, 26, 173-183. http://dx.doi.org/10.1023/a:1007953628840

CHEN, Z.Y., BROWN, R. L., DAMANN, K. E., CLEVELAND, T. E. 2004 Identification of a maize kernel tress-related protein and its effect on aflatoxin $\begin{array}{llll}\text { accumulation. } & \text { Phytopathology, } & 94(9), & 938-945\end{array}$ http://dx.doi.org/10.1094/phyto.2004.94.9.938

CHINNUSAMY V., SCHUMAKER, K AND ZHU, J. K. 2003. Molecular genetic perspectives on cross-talk and specificity in abiotic stress signaling in plants. J. Exp. Bo., 55, 225-236. http://dx.doi.org/10.1093/jxb/erh005

EL-SHABRAWI, H., KUMAR, B., KAUL, T, REDDY, M.K, SINGLAPAREEK, S.L., SOPORY, S.K. 2010. Redox homeostasis, antioxidant defense, and methylglyoxal detoxification as markers for salt tolerance in Pokkali rice Protoplasma, 245, 85-96. http://dx.doi.org/10.1007/s00709-010-0144-6

FOYER, C.H., NOCTOR, G. 2005a. Redox homeostasis and antioxidan signaling: A metabolic interface between stress perception and physiological responses. Plant Cell, 17, 1866-1875. http://dx.doi.org/10.1105/tpc.105.033589 FOYER, C.H., NOCTOR, G. 2005b. Oxidant and antioxidant signalling in plants: a reevaluation of the concept of oxidative stress in a physiological context. Plant Cell and Environment, 28, 1056-1071. http://dx.doi.org/10.1111/j.1365-3040.2005.01327.x

FOYER, C.H., NOCTOR, G. 2011. Ascorbate and glutathione: the heart of the redox hub. Plant Physiology, 155, 2-18 http://dx.doi.org/10.1104/pp.110.167569

GIDDINGS, G., ALLISON, G., BROOKS, D., CARTER, A. 2000. Transgenic plants as factories for biopharmaceuticals. Naure Biotechnol., 18, 1151-1155 http://dx.doi.org/10.1038/81132

HOQUE, M.A., URAJI, M., BANU, M.N.A., MORI, I.C., NAKAMURA, Y., MURATA, Y. 2010. The effect of methylglyoxal on glutathione S-transferase from Nicotiana tabacum. Bioscience Biotechnology and Biochemistry, 74(10), 2124-2126. http://dx.doi.org/10.1271/bbb.100393 
HORSCH, R. B., FRY, J., HOFFMANN, N., NIEDERMEYER, J., ROGERS, S G., FRALEY, T. F. 1988. Leaf disc transformation. Plant molecular biology manual. Kluwer, Dordrecht, 1-9p. http://dx.doi.org/10.1007/978-94-017-52947

HOSSAIN, M.A., FUJITA, M. 2009. Purification of glyoxalase I from onion bulbs and molecular cloning of its cDNA. Bioscience Biotechnology and Biochemistry, 73(9), 2007-2013. http://dx.doi.org/10.1271/bbb.90194

HOSSAIN, M.A.; FUJITA, M. 2010. Evidence for a role of exogenous glycinebetaine and proline in antioxidant defense and methylglyoxal detoxification systems in mung bean seedlings under salt stress. Physiology and Molecular Biology of Plants, 16(1), 19-29. http://dx.doi.org/10.1007/s12298010-0003-0

HOSSAIN, M.A., FUJITA, M. 2011. Regulatory role of components of ascorbate-glutathione (AsA-GSH) pathway in plant tolerance to oxidative stress. IK International Publishing House Pvt. Ltd., 81-147 p.

JEFFREY, M. S., BRADLEY, G., JULIE, G., PETER, T. J. H., PRISCILLA, H., NARENDER, N., VIKRAM, P., MICHAEL, S., JAMES, A. C., LORI, S., DANNETTE, W., GUANGNING, Y., DOUGLAS, A. R. 2000. High-yield production of a human therapeutic protein in tobacco chloroplasts. Nature biotechnology, 18, 333-338. http://dx.doi.org/10.1038/73796

KO, K., BRODZIK, R., STEPLEWSKI, Z. 2009. Production of antibodies in plants: approaches and perspectives. Curr. Top. Microbiol. Immunol., 332, 55-78. http://dx.doi.org/10.1007/978-3-540-70868-1 4

KUŹNIAK, E. 2010. The ascorbate-glutathione cycle and related redox signals in plantpathogen interactions., Springer, Dordrecht, The Netherlands, 115-136 p http://dx.doi.org/10.1007/978-90-481-9404-9 4

LAU, O.S., SUN, S.S.M. 2009. Plant seeds as bioreactors for recombinant protein production. Biotechnol. Adv., 27,1015-1022. http://dx.doi.org/10.1016/j.biotechadv.2009.05.005

LONGHURST, T., LEE, E., HINDE, R., BRADY, C., SPEIRS, J. 1994. Structure of the tomato Adh2 gene and Adh2 pseudogenes, and a study of Adh2 gene expression in fruit. Plant Mol. Biol., 26,1073-1084. http://dx.doi.org/10.1007/bf00040690

MHAMDI, A., QUEVAL, G., CHAOUCH, S., VANDERAUWERA, S., VAN BREUSEGEM, F., NOCTOR, G. 2010. Catalase function in plants: a focus on Arabidopsis mutants as stress-mimic models. Journal of Experimental Botany, 61(15), 4197-4220. http://dx.doi.org/10.1093/jxb/erq282

MUNNS, R. 2005. Genes and salt tolerance: bringing them together. New Phytologist, 167, 645-663. http://dx.doi.org/10.1111/j.1469-8137.2005.01487.x MURASHIGE, T., SKOOG, F. 1962. A revised medium for rapid growth and bioassays with tobacco tissue culture. Physiologia Plantarum, 15, 473-497. http://dx.doi.org/10.1111/j.1399-3054.1962.tb08052.x

MURRAY, M. G., THOMPSON, W. F. 1980. Rapid isolation of high molecularweight plant DNA. Nuc.l Acids Res., 8, 4321-4325. http://dx.doi.org/10.1093/nar/8.19.4321

RAY, A., ROY, C., MAZUMDER, M., SENGUPTA, D. N., RAY, M. 2011 Methylglyoxal destroys Agrobacterium tumefaciens crown gall tumours in Nicotiana tabacum without any adverse effect on the host plant. Biologia plantarum, 55 (2), 312-316. http://dx.doi.org/10.1007/s10535-011-0044-4

RAY, S., DUTTA, S., HALDER, J., RAY. 1994. Inhibition of electron flow through complex I of the mitochondrial respiratory chain of Ehrlich ascites carcinoma cells by methylglyoxal. Biochemical Journal, 303, 69-72.

ROMAGNANI, S., GIUDIZI, M.G., DEL PRETE, G., MAGGI, E., BIAGIOTTI, R., ALMERIGOGNA F. et al. 1982. Demonstration on protein A of two distinct immunoglobulin-binding sites and their role in the mitogenic activity of Staphylococcus aureus Cowan I on human B cells. J. Immunol., 129, 596602.

ROYCHOUDHURY, A., ROY, C., SENGUPTA, D. N. 2007. Transgenic tobacco plants overexpressing the heterologous lea gene Rab16A from rice during high salt and water deficit display enhanced tolerance to salinity stress. Plant Cell Report, 10, 299-371. http://dx.doi.org/10.1007/s00299-007-0371-2

SAMBROOK, J., RUSSEL, D.W. 2001. Molecular Cloning: A Laboratory Manual, $3^{\text {rd }}$ Edition, Cold Spring Harbor Laboratory Press, New York, NY, USA. SINGLA-PAREEK, S.L.; YADAV, S.K.; PAREEK, A.; REDDY, M.K.; SOPORY, S.K. 2006. Transgenic tobacco overexpressing glyoxalase pathway enzymes grow and set viable seeds in zinc-spiked soils. Plant Physiology, 140, 613-623. http://dx.doi.org/10.1104/pp.105.073734

STREATFIELD, S. J. 2007.Approaches to achieve high-level heterologous protein production in plants. Plant Biotechnol. J., 5, 2-15. http://dx.doi.org/10.1111/j.1467-7652.2006.00216.x

VEENA, REDDY., V.S., SOPORY, S. K. 1999. Glyoxalase I from Brassica juncea: molecular cloning, regulation and its over-expression confer tolerance in transgenic tobacco under stress. The Plant Journal, 17,385-395. http://dx.doi.org/10.1046/j.1365-313x.1999.00390.x

WARZECHA, H., MASON, H. S. 2003. Benefits and risks of antibody and vaccine production in transgenic plants. J Plant. Physiol., 160,755-64. http://dx.doi.org/10.1078/0176-1617-01125

WU, L., JUURLINK, B.H. 2002. Increased methylglyoxal and oxidative stress in hypertensive rat vascular smooth muscle cells. Hypertension, 39(3), 809-814. http://dx.doi.org/10.1161/hy0302.105207
XIONG, L. SCHUMAKER, K.S., ZHU, J.K. 2002. Cell signaling during cold, drought, and salt stress. Plant Cell, 14, 165-83.

YADAV, S.K., SINGLA-PAREEK, S.L., RAY, M., REDDY, M.K., SOPORY, S.K. 2005a. Methylglyoxal levels in plants under salinity stress are dependent on glyoxalase I and glutathione. Biochemical and Biophysical Research Communication, 337, 61-67. http://dx.doi.org/10.1016/j.bbrc.2005.08.263

YADAV, S.K., SINGLA-PAREEK, S.L., RAY, M., REDDY, M.K., SOPORY, S.K. 2005b. Transgenic tobacco plants overexpressing glyoxalase enzymes resist an increase in methylglyoxal and maintain higher reduced glutathione levels under salinity stress. FEBS Letters, 579, 6265-6271. http://dx.doi.org/10.1016/j.febslet.2005.10.006

YAMAGUCHI,T., BLUMWALD, E. 2005. Developing salt-tolerant crop plants: challenges and opportunities. Trends Plant Sci., 10(12), 616-619. http://dx.doi.org/10.1016/j.tplants.2005.10.002

YAMAGUCHI-SHINOZAKI，K., SHINOZAKI，K. (2006). Transcriptional regulatory networks in cellular responses and tolerance to dehydration and cold stresses. Anпual Review of Plant Biology, 57, 781-803. http://dx.doi.org/10.1146/annurev.arplant.57.032905.105444

YANG, Z. 2002. Small GTPases: versatile signaling switches in plants. Plant Cell, 14, 375-88. 